\title{
Babesia vesperuginis, a neglected piroplasmid: new host and geographical records, and phylogenetic relations
}

\author{
Alexandra Corduneanu ${ }^{1 *}$, Kristýna Hrazdilová2,13, Attila D. Sándor ${ }^{1}$, Ioana Adriana Matei ${ }^{1}$, Angela Monica lonică ${ }^{1}$, \\ Levente Barti ${ }^{3}$, Marius-Alexandru Ciocănău ${ }^{4}$, Dragoş Ștefan Măntoiu ${ }^{5}$, loan Coroiu ${ }^{6}$, Sándor Hornok ${ }^{7}$, \\ Hans-Peter Fuehrer $^{8}$, Natascha Leitner ${ }^{8}$, Zoltán Bagó ${ }^{9}$, Katharina Stefke $^{10}$, David Modrý ${ }^{2,11,12}$ \\ and Andrei Daniel Mihalca ${ }^{1}$
}

\begin{abstract}
Background: Babesia spp. are hemoparasites which infect the red blood cells of a large variety of mammals. In bats, the only known species of the genus is Babesia vesperuginis. However, except a few old reports, the host range and geographical distribution of this bat parasite have been poorly studied. This study aimed to investigate the presence of piroplasms in tissues of bats collected in four different countries from eastern and central Europe: Austria, Czech Republic, Hungary and Romania.

Methods: A total of 461 bat carcasses (24 species) were collected between 2001 and 2016 from caves, mines and buildings. PCR was performed using specific primers targeting a portion of the $18 \mathrm{~S}$ rDNA nuclear gene and cytochrome $c$ oxidase subunit 1 mitochondrial gene, followed by sequencing.

Results: The results of this study show for the first time the presence of $B$. vesperuginis in bats in central and eastern Europe. The phylogenetic analysis of the $18 \mathrm{~S}$ rDNA nuclear gene revealed no variability between the sequences and the phylogenetic analysis of the cox 1 mitochondrial gene proved that $B$. vesperuginis could be divided into two subclades.

Conclusion: Our study showed a broad geographical distribution of $B$. vesperuginis in European bats, reporting its presence in five new host species (M. cf. alcathoe, M. bechsteinii, M. myotis, Pi. nathusii and V. murinus) and three new countries.
\end{abstract}

Keywords: Bats, Tick-borne pathogens, Piroplasms, Babesia vesperuginis, Europe

\section{Background}

Chiroptera is the second largest order of mammals and includes about $20 \%$ of all mammal species worldwide [1]. Studies on the epidemiological role of chiropterans in the transmission of pathogens have focused mainly on zoonotic viruses such as rabies [2, 3], acute respiratory syndrome (SARS) [4], Ebola [5], Zika [6], and other viral disease (influenza, acute respiratory illness, chikungunya) [7]. Compared with other mammals, the role of bats in the transmission cycle of tick-borne protists $[8,9]$ and bacteria are less studied $[10,11]$. The life-cycle of most of

\footnotetext{
* Correspondence: alexandra.corduneanu@usamvcluj.ro

'Department of Parasitology and Parasitic Diseases, University of Agricultural Sciences and Veterinary Medicine of Cluj-Napoca, Cluj-Napoca, Romania

Full list of author information is available at the end of the article
}

the Babesia spp. in domestic animals is well known and involves a hard tick as a definitive host [12]. However, for bat piroplasms, the life-cycle (including a complete range of the vertebrate hosts) and the vectors involved are unknown.

Babesia vesperuginis was described by Dionisi [13] from Nyctalus noctula in Italy and later found also in Pipistrellus sp. in Italy [14]. The species was later reported in the UK [15] in blood smears of bats, followed by experimental transmission studies [16]. Concannon et al. [17] identified the infection with $B$. vesperuginis by PCR targeting the $18 \mathrm{~S}$ rDNA in six individuals from a total of 60 bats from Cornwall, UK, and they concluded that the parasite is different from other known Babesia. The only study outside Europe reports the presence of 
unidentified Babesia in Mormoops megalophylla from Colombia, with a low microscopic prevalence of $1.19 \%$ in blood smears [18]. In general, the diversity and ecology of bat piroplasmids remains unknown, and there is no data regarding how the parasite is transmitted. Hornok et al. [8] studied the presence of apicomplexan protozoans in bat faeces from Hungary and Romania. All samples were tested for the presence of piroplasms DNA with a conventional PCR and the positive samples (2.25\%) have shown similarity with Babesia canis.

The aim of this study was to investigate the presence of piroplasmids and their genetic diversity in bats from central and eastern Europe, namely from Austria, Czech Republic, Hungary and Romania based on partial sequences of nuclear $18 \mathrm{~S}$ rRNA and mitochondrial cox 1 genes to broaden the knowledge on their host spectrum, geographical distribution and phylogenetic relationships to other piroplasms.

\section{Methods}

Heart tissue from 461 bats collected in four different countries (Austria, Czech Republic, Hungary and Romania) between 2001 and 2016 were examined (Additional file 1: Table S1, Fig. 1). All animals were found either as accidental kills of wind power generators, dead due to natural causes or euthanized because of progressive deterioration of general condition (in few captive specimens). A wind farm in Babadag, Romania, consisting of 20 turbines was monitored for a period of four years (2013-2016) using a weekly time frame with two consecutive days of carcass searches, from April to November. Bat carcases were found either fresh or desiccated. Samples were collected from carcasses which have been labelled fresh. These have been found on the second day of each weekly field visit and presented no signs of maggots or decomposition. All bats were identified according to morphological keys [19] and stored in $96 \%$ ethanol, at $-80{ }^{\circ} \mathrm{C}$ (samples from Austria) or in a freezer until their necropsy. Morphological identification of whiskered bats from the Myotis mystacinus group (M. alcathoe, M. brandtii and $M$. mystacinus) is not only problematic, but these species may show signs of hybridization [20]. Therefore, we distinguished these as the 'most likely' morphological species (e.g. Myotis cf. alcathoe in case of a bat identified morphologically as $M$. alcathoe). Genomic DNA was extracted from $25 \mathrm{mg}$ of heart tissue using DNeasy Blood \& Tissue Kit (Qiagen, Hilden, Germany), according to the manufacturer's instruction and stored at $-20{ }^{\circ} \mathrm{C}$.

A nested PCR targeting a $561 \mathrm{bp}$ fragment of $18 \mathrm{~S}$ rDNA using previously described primers [21, 22] was used for initial screening. The reactions were carried out in a $25 \mu \mathrm{l}$ reaction mixture containing $12.5 \mu \mathrm{l} 2 \times$ Green PCR Master Mix (Rovalab GmBH, Teltow, Germany), $5.5 \mu \mathrm{l}$ water, $1 \mu \mathrm{l}$ of each primer $(10 \mathrm{pmol} / \mu \mathrm{l})$ and $5 \mu \mathrm{l}$ aliquot of isolated DNA in the first round and in the second round instead of DNA $2 \mu \mathrm{l}$ of PCR product from the first round was used. The PCR was performed using the $\mathrm{T} 1000^{\mathrm{m}}$ Thermal Cycler (Bio-Rad, London, UK) with the following condition: initial denaturation at $95{ }^{\circ} \mathrm{C}$ for $3 \mathrm{~min}$, then 40 cycles of denaturation at $95{ }^{\circ} \mathrm{C}$ for $30 \mathrm{~s}$, annealing at $60{ }^{\circ} \mathrm{C}$ for $30 \mathrm{~s}$ (for the first round), $50{ }^{\circ} \mathrm{C}$ for $30 \mathrm{~s}$ (for the second round) and extension at $72{ }^{\circ} \mathrm{C}$ for $1 \mathrm{~min}$ (for the first round), $72{ }^{\circ} \mathrm{C}$ for $40 \mathrm{~s}$ (for the second round) and a final extension at $72{ }^{\circ} \mathrm{C}$ for $7 \mathrm{~min}$.

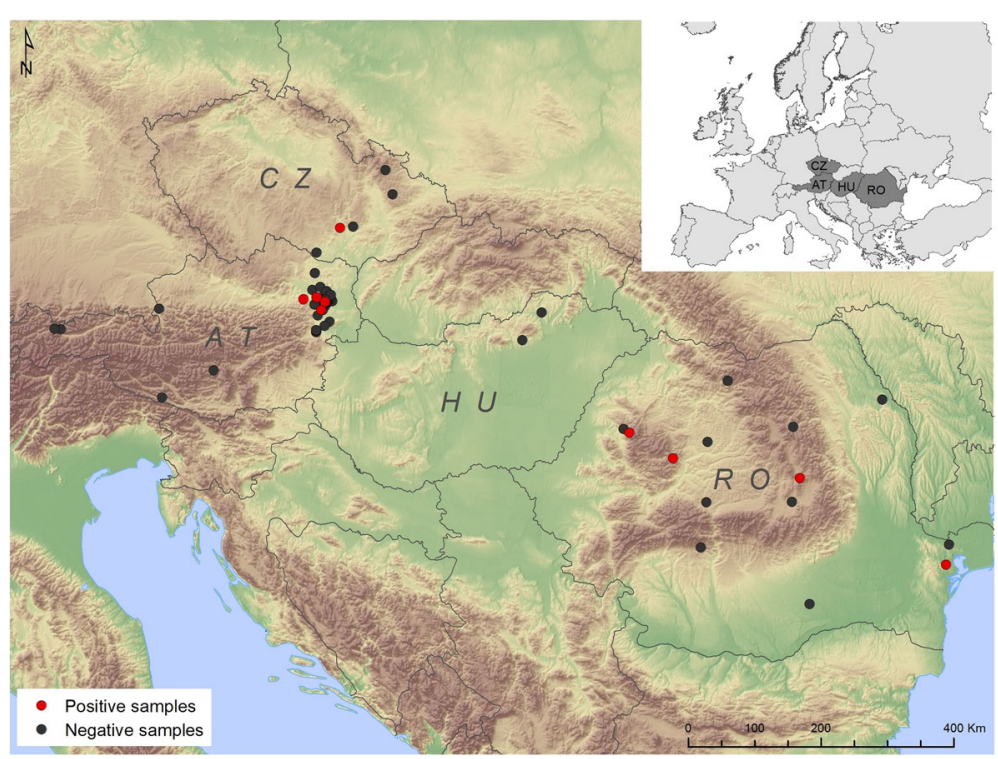

Fig. 1 Sampling sites: red dots represent the positive locations for Babesia vesperuginis; black dots represent the negative locations (including multiple samples from the same place). Abbreviations: AT, Austria; CZ, Czech Republic; HU, Hungary; RO, Romania 
For each set of reactions (45 samples) 2 negative controls (distilled water) and one positive control which was DNA isolated from the blood of a naturally infected dog with Babesia canis were included.

For the samples positive for $18 \mathrm{~S}$ rDNA, an additional nPCR targeting the cox 1 gene was applied using a modified protocol described by Gou et al. [23] with the following primers Bab_For1: (5'-ATW GGA TTY TAT ATG AGT AT-3'), Bab_Rev1: (5'-ATA ATC WGG WAT YCT CCT TGG-3') for the first round and Bab_For2: (5'-TCT CTW CAT GGW TTA ATT ATG ATA T-3'), Bab_Rev2: (5' -TAG CTC CAA TTG AHA RWA CAA AGT G-3') for the second round. The amplification was performed as follows: $25 \mu \mathrm{l}$ reaction mixture containing $2 \mu \mathrm{l}$ aliquot of isolated DNA in the first round and $1 \mu \mathrm{l}$ in the second, $12.5 \mu \mathrm{l}$ Master Mix (PCRBIO Taq Mix Red), $1 \mu \mathrm{l}$ of each primer $(10 \mathrm{pmol} / \mu \mathrm{l})$ and $8.5 \mu \mathrm{l}$ water. The amplification profile consisted of $1 \mathrm{~min}$ of initial denaturation at $95^{\circ} \mathrm{C}$, followed by 35 cycles of denaturation at $95{ }^{\circ} \mathrm{C}$ for $15 \mathrm{~s}$, annealing at $45^{\circ} \mathrm{C}$ for $30 \mathrm{~s}$ (for the first round), $49{ }^{\circ} \mathrm{C}$ for $30 \mathrm{~s}$ (for the second round) and extension at $72{ }^{\circ} \mathrm{C}$ for $1 \mathrm{~min}$, and a final extension at $72{ }^{\circ} \mathrm{C}$ for $10 \mathrm{~min}$.

Amplification products were visualized by electrophoresis on $1.5 \%$ agarose gel stained with RedSafe ${ }^{\text {ti }} 20,000 \times$ Nucleic Acid Staining Solution (Chembio, St Albans, UK), and their molecular weight was assessed by comparison to a molecular marker (O'GeneRuler ${ }^{\mathrm{TM}} 100 \mathrm{bp}$ DNA Ladder, Thermo Fisher Scientific Inc., Waltham, MA, USA). PCR products were purified using the QIAquick PCR purification kit (Qiagen, Hilden, Germany) and sent for sequencing (Macrogen Europe, Amsterdam, Netherlands).

The sequences were compared with those available in GenBank $^{\text {tm }}$ using Basic Local Alignments Tool (BLAST) analyses. All sequences were analysed and edited using Geneious $^{\circ}$ 9.1.2 software [24]. Alignments of non-coding (18S rDNA) sequences were generated using the ClustalW algorithm [25]. For coding cox1 sequences, translational alignment (nucleotide sequences are translated into protein, the alignment was performed on the protein sequence, and then translated back to nucleotide sequence) implemented in Geneious ${ }^{-9.1 .2}$ using ClustalW algorithm was performed. The evolution model for each dataset was chosen based on likelihood ratio test computed by R software (R Core Team, 2012). Phylogenetic analyses were performed using the maximum likelihood method in PhyML 3.0 software [26]. Phylogenetic trees were visualized and edited in FigTree v1.4.1 (http://tree.bio.ed.ac.uk/ software/figtree/).

Statistical analysis was performed using EpiInfo ${ }^{\text {tw }} 7$ software (CDC, USA). The overall prevalence of $B$. vesperuginis, the prevalence at locality level and the prevalence of each bat species and their 95\% confidence interval (95\% CI) were calculated. The map was generated using ArcGIS 10.3 software (Fig. 1).

\section{Results}

PCR targeting 18S rDNA revealed the presence of piroplasmid DNA in 20 out of 461 bats $(4.34 \%, 95 \% \mathrm{CI}$ : 2.83-6.61). The positive samples originated from 9 different locations from three different countries, belonging to seven bat species (Tables 1 and 2). Babesia vesperuginis was present in Myotis cf. alcathoe (1/12), M. bechsteinii (1/4), M. myotis (1/6), N. noctula (4/246), P. nathusii (3/28), P. pipistrellus (6/71) and Vespertilio murinus $(4 / 23)$. The following species were negative (numbers of examined specimens in parentheses): Barbastella barbastellus $(n=2)$, Eptesicus nilssonii $(n=1), E$. serotinus $(n=6)$, Hypsugo savii $(n=11)$, Miniopterus schreibersii $(n=4), M$. cf. brandtii $(n=3), M$. daubentonii $(n=1), M$. cf. mystacinus $(n=4), M$. nattereri $(n=1)$, $N$. leisleri $(n=5)$, Pi. kuhlii $(n=8)$, Pi. pygmaeus $(n=5)$, Pl. auritus $(n=8), P l$. austriacus $(n=1)$, Rhinolophus euryale $(n=9)$, R. ferrumequinum $(n=1)$ and $R$. hipposideros $(n=1)$.

BLAST analysis of the $18 \mathrm{~S}$ rDNA sequences from the 20 positive samples showed a 96 to $100 \%$ similarity to $B$. vesperuginis (GenBank: AJ871610.1) isolated from Pipistrellus sp. in the UK. All sequences obtained from bat tissues were highly similar, except a single one from a $M$. myotis sample (GenBank: MG011464) (Peştera cu Apă din Valea Leșului, Romania), which differed by two nucleotides (Fig. 2). All sequences were submitted to the GenBank database under the accession numbers MG011454-MG011473.

Additional cox1 PCR applied to all 18S rDNA positive samples showed a lower success of amplification (17/20). No $\operatorname{cox} 1$ sequences were available from $B$. vesperuginis in GenBank for comparative analysis. The BLAST analysis of all 17 cox 1 sequences showed maximum $78 \%$ similarity with different isolates of Babesia and Theileria. Based on these data, a broad phylogenetic analysis including also the most related Theileria spp. cox1 sequences (clade no. $\mathrm{V}$, according to Schnittger et al. [27]) was performed to confirm the phylogenetic relationships of $B$. vesperuginis with a broader range of piroplasmids (data not shown in our tree). Our B. vesperuginis cox 1 sequences remained in a basal position within the Babesia clade VI, thus confirming the $18 \mathrm{~S}$ rDNA based phylogeny. From the 17 cox 1 sequences, 14 were similar amongst each other, forming a subclade with identity above $99.65 \%$ (maximum difference of $3 \mathrm{nt}$ within $864 \mathrm{nt}$ used for the phylogeny) and three of them forming a separate subclade of almost identical sequences (1 nt difference in sequence with the accession number MF996541). The subclades differ by 15-19 nt (within $861 \mathrm{nt}$ fragments) among each other (Fig. 3). All sequences were submitted to the GenBank database under the accession numbers: MF996533-MF996549. 
Table 1 Prevalence (\%) and frequency (in parentheses) of Babesia vesperuginis in the positive bat species in each locality

\begin{tabular}{|c|c|c|c|c|c|c|c|c|c|}
\hline \multirow{2}{*}{$\begin{array}{l}\text { Locality } \\
\text { Species }\end{array}$} & \multicolumn{4}{|l|}{ Austria } & \multicolumn{3}{|c|}{ Czech Republic } & \multicolumn{2}{|l|}{ Romania } \\
\hline & Mauerbach & Mödling & Neulengbach & Vienna & Brno & Babadag & Huda lui Papară & Muntele Puciosu & $\begin{array}{l}\text { Peşterea cu apă } \\
\text { din Valea Leşului }\end{array}$ \\
\hline Myotis alcathoe & - & - & - & - & - & - & - & $8.33(1 / 12)$ & - \\
\hline Myotis bechsteinii & - & - & - & - & - & - & - & $25(1 / 4)^{a}$ & - \\
\hline Myotis myotis & - & - & - & - & - & - & - & - & $100(1 / 1)^{a}$ \\
\hline Nyctalus noctula & - & - & - & - & $\begin{array}{l}9.09 \\
(1 / 11)\end{array}$ & $\begin{array}{l}8.33 \\
(1 / 12)\end{array}$ & $18.18(2 / 11)$ & - & - \\
\hline Pipistrellus nathusii & - & - & - & - & - & $12(3 / 25)$ & - & - & - \\
\hline Pipistrellus pipistrellus & $100(1 / 1)^{\mathrm{a}}$ & - & $100(1 / 1)$ & - & $6.66(1 / 15)$ & - & $5.66(3 / 53)$ & - & - \\
\hline Vespertilio murinus & $100(1 / 1)$ & $100(1 / 1)$ & - & $9.09(1 / 11)$ & - & - & - & $50(1 / 2)$ & - \\
\hline
\end{tabular}

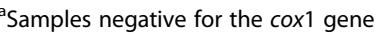

\section{Discussion}

The samples collected for the present study originated from 24 bat species from three families including the Miniopteridae, Rhinolophidae and Vespertilionidae. All the positive animals belonged to five different genera of the Vespertilionidae. As the number of examined specimens from the other two families was low, we do not feel confident in establishing or refuting their host status for B. vesperuginis. Except for N. noctula and Pi. pipistrellus [13-17], all other bat species (M. cf. alcathoe, $M$. bechsteinii, M. myotis, Pi. nathusii and $V$. murinus) are new host records for $B$. vesperuginis. Our study shows for the first time the presence of $B$. vesperuginis in tissues of bats from Austria, Czech Republic and Romania.

Hornok et al. [8] found Babesia spp. in faeces of insectivorous bats and suggested as a likely way of infection the food ingested by bats [8]. All positive bat species forage over a range of habitats including deciduous forests, woodland edge, wetland, pasture [19]. The food of most of the positive species consists of small insects like moths [28, 29], mosquitoes [30, 31] and small dipterans [19]. The prey is caught during flight (M. alcathoe, Pi. nathusii, Pi.

Table 2 Samples from the phylogenetic analysis of 18S rRNA nuclear gene (GenBank Accesion numbers provided) and cox1 mitochondrial gene

\begin{tabular}{|c|c|c|c|}
\hline Abbreviation & Species & Location & GenBank ID \\
\hline Bat 1 & Nyctalus noctula & Brno (CZ) & MG011454 \\
\hline Bat 2 & Nyctalus noctula & $\mathrm{Brno}(\mathrm{CZ})$ & MG011455 \\
\hline Bat 4 & Vespertilio murinus & Vienna (AT) & MG011456 \\
\hline Bat 5 & Vespertilio murinus & Mödling AT) & MG011457 \\
\hline Bat 6 & Vespertilio murinus & Mauerbach (AT) & MG011458 \\
\hline Bat 7 & Pipistrellus pipistrellus & Neulengbach (AT) & MG011459 \\
\hline Bat 8 & Pipistrellus pipistrellus & Mauerbach (AT) & MG011460 \\
\hline Bat 9 & Vespertilio murinus & Muntele Puciosu (RO) & MG011461 \\
\hline Bat 10 & Myotis alcathoe & Muntele Puciosu (RO) & MG011462 \\
\hline Bat 11 & Myotis bechsteinii & Muntele Puciosu (RO) & MG011463 \\
\hline Bat 12 & Myotis myotis & Peşterea cu apă din Valea Leşului (RO) & MG011464 \\
\hline Bat 13 & Nyctalus noctula & Huda lui Papară (RO) & MG011465 \\
\hline Bat 14 & Nyctalus noctula & Muntele Puciosu (RO) & MG011466 \\
\hline Bat 15 & Vespertilio murinus & Mauerbach (AT) & MG011467 \\
\hline Bat 16 & Pipistrellus nathusii & Babadag (RO) & MG011468 \\
\hline Bat 17 & Pipistrellus nathusii & Babadag (RO) & MG011469 \\
\hline Bat 18 & Nyctalus noctula & Babadag (RO) & MG011470 \\
\hline Bat 19 & Pipistrellus nathusii & Babadag (RO) & MG011471 \\
\hline Bat 20 & Pipistrellus pipistrellus & Huda lui Papară (RO) & MG011472 \\
\hline Bat 21 & Pipistrellus pipistrellus & Huda lui Papară (RO) & MG011473 \\
\hline
\end{tabular}




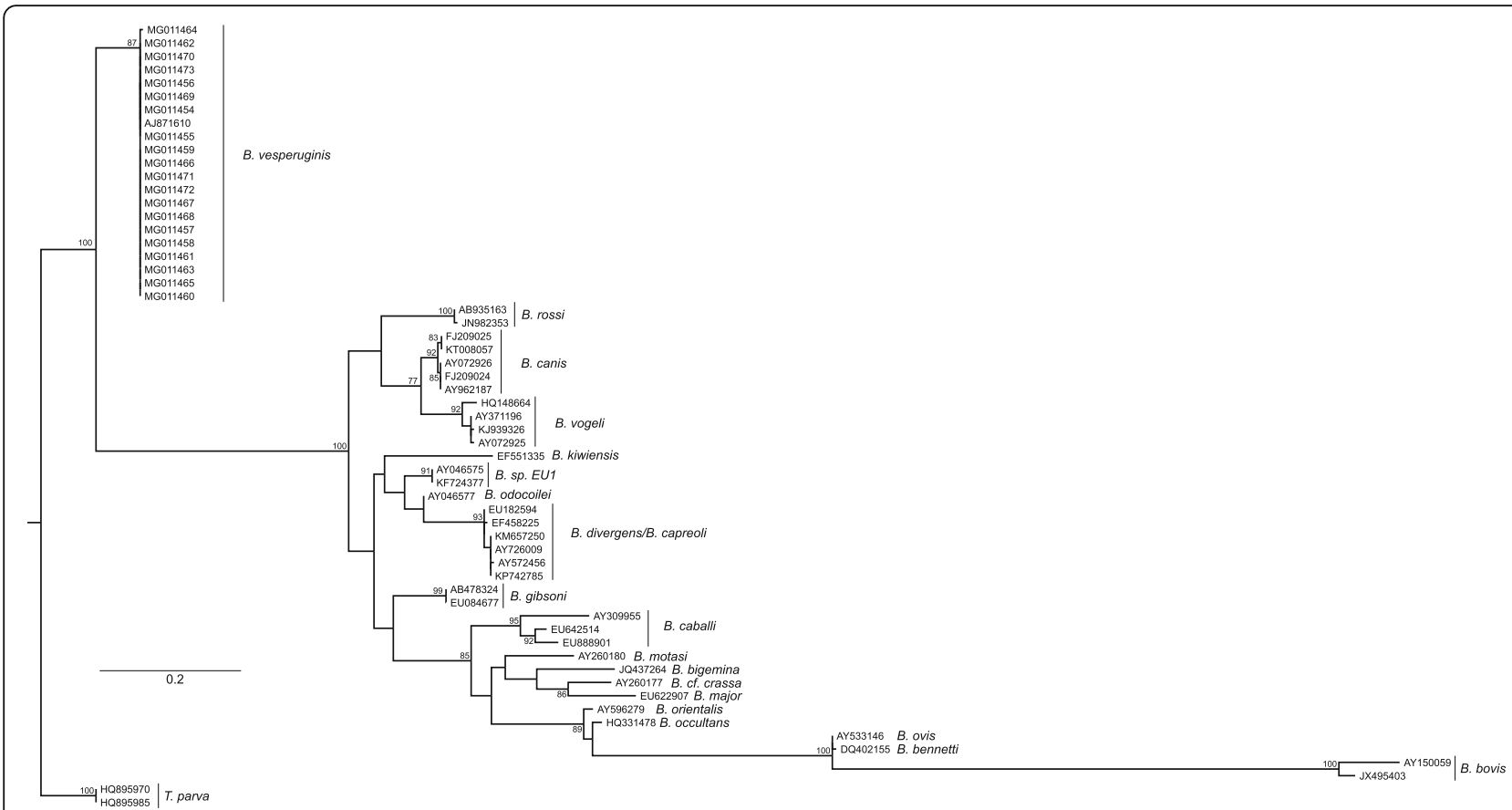

Fig. 2 Phylogenetic tree constructed by maximum likelihood method on nucleotide sequences of 18S rRNA gene (fragment of $515 \mathrm{nt}$ ) of piroplasmid clade VI according to Schnittger et al. [27]. Details for sequences generated in the present study (host species and country of sample origin) are provided in Table 2. Proportion from 1000 replicates of bootsrap values only above $75 \%$ are displayed. Theileria parva sequences were used as the outgroup



Fig. 3 Phylogenetic tree constructed by maximum likelihood method on translational alignment of nucleotide sequence of coding region of cox1 gene (fragment $861 \mathrm{nt}$ ) of piroplasmid clade VI according to Schnittger et al. [27]. Details for sequences generated in the present study (host species and country of sample origin) are provided in Table 2. Proportion from 1000 replicates of bootsrap values only above $75 \%$ are displayed. Theileria spp. sequences were used as the outgroup 
pipistrellus, $V$. murinus) or picked up from various surfaces (M. bechsteinii). There are two exceptions: $N$. noctula feeds on medium sized insects (dipterans, beetles, caddis flies) during flight and $M$. myotis feeds from the ground, on beetles, large moths, crickets and spiders [19]. By selecting food in such varied habitat types, bats may encounter the (yet) unknown vector for $B$. vesperuginis.

Another hypothesis regarding the vector of $B$. vesperuginis was presented by Gardner et al. [17] suggesting that a bat specific soft tick (Argas vespertilionis) may be the vector for this piroplasm species. While we did not find any soft ticks on the bats analysed, these animals might have been parasitized before at their roosts. As only larvae of soft ticks spend longer time on their hosts, their presence is hard to be detected [32, 33].

The roosting sites of sampled species are in tree hollows, buildings, cracks in cliffs or caves for the summer and underground habitats, caves for the winter except $V$. murinus which hibernates in rock fissures and crevices in tall buildings [19]. All species usually form mixed colonies with congeneric species (e.g. M. bechsteinii with $M$. daubentonii). In other cases, roosts may contain mixed colonies, with species from different genera (e.g. M. myotis with Rhinolophus spp.). In hibernating sites, even species which roost in trees may encounter a wide variety of ectoparasites, including soft ticks. Some species are sedentary (M. alcathoe, M. bechsteinii, Pi. pipistrellus) [19], others are adapted to migration over a few hundred kilometres (M. myotis) [19] and others migrate for long-distance, up to $2000 \mathrm{~km}$ (N. noctula, Pi. nathusii, V. murinus) [19, 34]. Long distance migrants feed on the go, fuelling their energy loss while migrating [34]. The range of species studied and their diverse ecology showed that $B$. vesperuginis has a wide geographical distribution among different bat populations; it can be spread over a long distance and has low bat host specificity. Most of the bat species that were negative for the presence of $B$. vesperuginis are sedentary, except Mi. schreibersii and $N$. leisleri. However, in most of the cases, the negativity of certain bat species for $B$. vesperuginis might have been a consequence of the small sample size.

Gardner et al. [15] found B. vesperuginis in two species: Pi. pipistrellus (19/206, 9.22\%) and M. mystacinus (1/11, 9.09\%) in UK. Concannon et al. [17] examined by PCR (targeting 18S rDNA) the heart tissue of bats and found $B$. vesperuginis only in Pipistrellus sp. $(6 / 60,10 \%)$ in the UK. All records of $B$. vesperuginis, including the present study, indicate that the main host species for $B$. vesperuginis in Europe are N. noctula and Pipistrellus spp.

The phylogenetic analysis of the $2018 \mathrm{~S}$ rDNA sequences showed no variability between them. However, when the more variable cox 1 gene was used, the phylogeny demonstrated the presence of a widely distributed clade (five host species, eight localities from Austria,
Czech Republic and Romania) and a smaller one, with two host species ( $N$. noctula and Pi. nathusii). In two localities (Babadag and Huda lui Papară, Romania), sequences included in both subclades of the cox 1 tree were present.

The life-cycle of $B$. vesperuginis is unknown. Gardener et al. [15] suggested the involvement of Argas vespertilionis as a vector, as this soft tick was found on the majority of the Pi. pipistrellus bats infected with $B$. vesperuginis. Similarly, only soft ticks (Ornithodoros marinkellei and Antricola mexicanus) were found on Mormoops megalophylla bats infected with Babesia sp. in Colombia [19]. However, the presence of $B$. vesperuginis has never been tested in soft ticks of bats. Moreover, for nearly all the Babesia species with a known life-cycle, the vector is a hard tick [35], suggesting a close co-evolution of piroplasms with the family Ixodidae. Nevertheless, Babesia meri is transmitted by Ornithodoros erraticus to the fat sand rat (Psammomys obesus) [36]. In addition, circumstantial evidence indicates the possible role of O. moubata (Argasidae) in the transmission of $B$. gibsoni in dogs after being artificially infected with this parasite [37], showing that the involvement of a soft tick in the life-cycle of Babesia sp. is possible. All hard ticks identified (a few individuals) on the individual bats included in the present study were examined and proved negative for the presence of $B$. vesperuginis in a different study [9].

\section{Conclusion}

Our study showed a broad geographical distribution of $B$. vesperuginis in European bats, reporting its presence in five new host species (My. cf. alcathoe, My. bechsteinii, My. myotis, Pi. nathusii, V. murinus). The low variability of $18 \mathrm{~S}$ rDNA and cox 1 sequences and a large number of confirmed host species suggest low host specificity of this piroplasmid and imply the involvement of a rather ubiquitous vector.

\section{Additional file}

Additional file 1: Table S1. Samples distribution according to species and locality. (XLSX $15 \mathrm{~kb}$ )

\section{Acknowledgements}

We are grateful for the help of our collaborators during field work and sample collection: Lucie Dufková, Daniel Ruzek, Péter Estók, Sándor Boldogh, Irina Pocora, Viorel Pocora, Teodor Dan Ursache and to Cristian Domşa for the distribution map.

\section{Funding}

This research was supported from grants TE 36/2015 and TE 298/2015, by projects of The Ministry of Education, Youth and Sports of the Czech Republic CEITEC 2020 (LQ1601), COST CZ LD14048, project LO1218 with financial support from the Ministry of Education, Youth and Sports of the Czech Republic under the NPU I programme. We acknowledge a grant for the development of research organization (RVO: RO0516). This paper was prepared under the frame of EurNegVec COST Action TD1303. 


\section{Availability of data and materials}

The data supporting the conclusion of this article are provided within the article and its additional file. Sequences are submitted to the GenBank database under the accession numbers MG011454-MG011473 (18S rDNA) and MF996533-MF996549 (cox1)

\section{Authors' contributions}

$A C, D M$ and $A D M$ wrote the manuscript. ADS, LB, DSM, IC, SH, ZB and KS collected the material for the study. ADS, DȘM, IC, SH, NL, ZB and KS helped in the identification of bat species. AC, IAM, AMI and MAC did the necropsies, $\mathrm{AC}$ and $\mathrm{KH}$ performed laboratory work and analysis of the data. ADS, IAM, AMI, SH and HPF participated in manuscript correction. All authors read and approved the final manuscript.

\section{Ethics approval and consent to participate}

Not applicable.

\section{Consent for publication}

Not applicable.

\section{Competing interests}

The authors declare that they have no competing interests.

\section{Publisher's Note}

Springer Nature remains neutral with regard to jurisdictional claims in published maps and institutional affiliations.

\section{Author details}

'Department of Parasitology and Parasitic Diseases, University of Agricultural Sciences and Veterinary Medicine of Cluj-Napoca, Cluj-Napoca, Romania. ${ }^{2}$ CEITEC VFU, University of Veterinary and Pharmaceutical Sciences, Brno, Czech Republic. ${ }^{3}$ Romanian Bat Protection Association- Central Branch, Odorheiu Secuiesc, Romania. ${ }^{4}$ Department of Infection Diseases, University of Agronomical Sciences and Veterinary Medicine, Bucharest, Romania. Institute of Speleology 'Emil Racoviță', Cluj-Napoca, Romania. ${ }^{6}$ Faculty of Biology and Geology, University Babes- Bolyai, Cluj-Napoca, Romania. ${ }^{7}$ Department of Parasitology and Zoology, University of Veterinary Medicine, Budapest, Hungary. ${ }^{8}$ Institute of Parasitology, Department of Pathobiology, University of Veterinary Medicine, Vienna, Austria. ${ }^{9}$ Institute for Veterinary Disease Control, Austrian Agency for Health and Food Safety (AGES), Robert Koch Gasse 17, 2340 Mödling, Austria. ${ }^{10}$ Museum of Natural History, Vienna, Austria. ${ }^{11}$ Department of Pathology and Parasitology, University of Veterinary and Pharmaceutical Sciences, Brno, Czech Republic. ${ }^{12}$ Biology Centre, Institute of Parasitology, Czech Academy of Sciences, České Budějovice, Czech Republic. ${ }^{13}$ Department of Virology, Veterinary Research Institute, Hudcova 296/70, 62100 Brno, Czech Republic.

Received: 12 April 2017 Accepted: 14 November 2017

Published online: 06 December 2017

\section{References}

1. Tsang SM, Cirranello AL, Bates PJ, Simmons NB. The roles of taxonomy and systematics in bat conservation. In: Voight C, Kingston T, editors. Bats in the Anthropocene: conservation of bats in a changing world. Springer, Cham; 2016. p. 503-38

2. Castilho JG, De Souza DN, Oliveira RN, Carnieli PJ, Batista HB, Pereira PM, et al. The epidemiological importance of bats in the transmission of rabies to dogs and cats in the state of Säo Paulo, Brazil, between 2005 and 2014. Zoonoses Public Health. 2017:64(6):423-30.

3. Schneider MC, Romijn PC, Uieda W, Tamayo H, da Silva DF, Belotto A, et al. Rabies transmitted by vampire bats to humans: an emerging zoonotic disease in Latin America? Rev Panam Salud Publica. 2009;25(3):260-9.

4. Drexler JF, Gloza-Rausch F, Glende J, Corman VM, Muth D, Goettsche M, et al. Genomic characterization of severe acute respiratory syndrome-related coronavirus in European bats and classification of coronaviruses based on partial RNA-dependent RNA polymerase gene sequences. J Vir. 2010;84(21): 11336-49.

5. Brook CE, Dobson AP. Bats as 'special' reservoirs for emerging zoonotic pathogens. Trends Microbiol. 2015;23(3):172-80.

6. Kading RC, Schountz T. Flavivirus infections of bats: potential role in Zika virus ecology. Am J Med Hyg. 2016;95(5):993-6.
7. Calisher $\mathrm{CH}$, Childs JE, Field HE, Holmes KV, Schountz T. Bats: important reservoir hosts of emerging viruses. Clin Microbiol Rev. 2006;19(3):531-45.

8. Hornok S, Estók P, Kováts D, Flaisz B, Takács N, Sz ke K, et al. Screening of bat faeces for arthropod-borne apicomplexan protozoa: Babesia canis and Besnoitia besnoiti-like sequences from Chiroptera. Parasit Vectors. 2015;8:441.

9. Hornok S, Szőke K, Kováts D, Estók P, Gőrfől T, Boldogh SA, et al. DNA of piroplasms of ruminants and dogs in ixodid bat ticks. PLoS One. 2016; 11(12):e0167735.

10. Bai Y, Urushadze L, Osikowicz L, McKee C, Kuzmin I, Kandaurov A, et al. Molecular survey of bacterial zoonotic agents in bats from the country of Georgia (Caucasus). PLoS One. 2017;12(1):e0171175.

11. Mühldorfer K. Bats and bacterial pathogens: a review. Zoonoses Public Health. 2013;60(1):93-103.

12. Solano-Gallego L, Baneth G. Babesiosis in dogs and cats - expanding parasitological and clinical spectra. Vet Parasitol. 2011;181(1):48-60.

13. Dionisi A. Les parasites endoglobulaires des chauves-souris. Atti della Reale Academia dei Lincei. 1898;7:153-6.

14. Dionisi A. La malaria di alcuni specie di pipistrelli. Atti della Societa per gli studi Malaria. 1899;1:133-73.

15. Gardner RA, Molyneux DH, Stebbings RE. Studies on the prevalence of haematozoa of British bats. Mammal Rev. 1987;173:75-80.

16. Gardner RA, Molyneux DH. Babesia vesperuginis: natural and experimental infections in British bats (Microchiroptera). Parasitology. 1987;95:461-9.

17. Concannon R, Wynn-Owen K, Simpson VR, Birtles RJ. Molecular characterization of haemoparasites infecting bats (Microchiroptera) in Cornwall, UK. Parasitology. 2005;131(Pt 4):489-96.

18. Marinkelle CJ. Babesia sp. in Colombian bats (Microchiroptera). J Wildl Dis. 1996:32(3):534-5.

19. Dietz C, Nill D, von Helversen O. Bats of Britain, Europe and Northwest Africa. London: A\&C Black; 2009.

20. Bogdanowicz W, Piksa K, Tereba A. Hybridization hotspots at bat swarming sites. PLoS One. 2012;7(12):e53334.

21. Hodžić A, Alić A, Fuehrer HP, Harl J, Wille-Piazzai W, Duscher GGA. Molecular survey of vector-borne pathogens in red foxes (Vulpes vulpes) from Bosnia and Herzegovina. Parasit Vectors. 2015;8:88.

22. Zintl A, Finnerty EJ, Murphy TM, De Waal T, Gray JS. Babesias of red deer (Cervus elaphus) in Ireland. Vet Res. 2011;42:7.

23. Gou H, Guan G, Liu A, Ma M, Xu Z, Liu Z, et al. A DNA barcode for Piroplasmea. Acta Trop. 2012;124(1):92-7.

24. Kearse M, Moir R, Wilson A, Stones-Havas S, Cheung M, Sturrock S, et al. Geneious basic: an integrated and extendable desktop software platform for the organization and analysis of sequence data. Bioinformatics. 2012;28(12):1647-9.

25. Larkin MA, Blackshields G, Brown NP, Chenna R, McGettigan PA, McWilliam $H$, et al. Clustal W and Clustal X version 2.0. Bioinformatics. 2007;23(21):2947-8

26. Guindon S, Gascuel OA. Simple, fast, and accurate algorithm to estimate large phylogenies by maximum likelihood. Syst Biol. 2003; 52(5):696-704.

27. Schnittger L, Rodriguez AE, Florin-Christensen M, Morrison DA. Babesia: a world emerging. Infect Genet Evol. 2012:12(8):1788-809.

28. Danko Š, Krištin A, Krištofik J. Myotis alcathoe in eastern Slovakia: occurrence, diet, ectoparasites and notes on its identification in the field. Vespertilio. 2010;13-14:77-91.

29. Lučan RK, Andreas M, Benda P, Bartonička T, Březinová T, Hoffmannová A et al. Alcathoe bat (Myotis alcathoe) in the Czech Republic: distributional status, roosting and feeding ecology. Acta Chiropterol. 2009;11(1):61-9.

30. Krüger F, Clare EL, Symondson WOC, Keišs O, Peterson G. Diet of the insectivorous bat Pipistrellus nathusii during autumn migration and summer residence. Mol Ecol. 2014;23(15):3672-83.

31. Fenton MB, Bogdanowicz W. Relationships between external morphology and foraging behaviour: bats in the genus Myotis. Can J Zool. 2002;80(6):1004-13.

32. Hoogstraal H. Bat ticks of the genus Argas (Ixodoidea, Argasidae). The subgenus Carios. A redescription of A. (C.) vespertilionis (Latreille, 1802), and variation within an Egyptian population. Ann Ent Soc Am. 1958:51:19-26.

33. Guglielmone AA, Robbins RG, Apanaskevich DA, Petney TN, Estrada-Pena A, Horak IG, et al. The Argasidae, Ixodidae and Nuttalliellidae (Acari: Ixodida) of the world: a list of valid species names. Zootaxa. 2010;2528:1-28. 
34. Voigt CC, Sorgel K, Suba J, Keiss O, Petersons G. The insectivorous bat Pipistrellus nathusii uses a mixed- fuel strategy to power autumn migration. Proc Biol Sci. 2012;279(1743):3772-8.

35. Hunfeld KP, Hildebrandt A, Gray JS. Babesiosis: recent insights into an ancient disease. Int J Parasitol. 2008;38(11):1219-37.

36. Gunders AE, Hadani A. An argasid tick, Ornithodoros erraticus (Lucas) a natural vector of Nuttallia meri. Z Tropenmed Parasit. 1973;24(4):536-8.

37. Battsetseg B, Matsuo T, Xuan X, Boldbaatar D, Chee SH. Babesia parasites develop and are transmitted by the non-vector soft tick Ornithodoros moubata (Acari: Argasidae). Parasitology. 2006;134(Pt 1):1-8.

Submit your next manuscript to BioMed Central and we will help you at every step:

- We accept pre-submission inquiries

- Our selector tool helps you to find the most relevant journal

- We provide round the clock customer support

- Convenient online submission

- Thorough peer review

- Inclusion in PubMed and all major indexing services

- Maximum visibility for your research

Submit your manuscript at www.biomedcentral.com/submit 